\title{
Reducing pain during vaccine injections: clinical practice guideline
}

\author{
Anna Taddio MSc PhD, C. Meghan McMurtry PhD, Vibhuti Shah MD MSc, Rebecca Pillai Riddell PhD, \\ Christine T. Chambers PhD, Melanie Noel PhD, Noni E. MacDonald MD, Jess Rogers BA, Lucie M. Bucci MA, \\ Patricia Mousmanis MD, Eddy Lang MD, Scott A. Halperin MD, Susan Bowles PharmD, \\ Christine Halpert RN MA, Moshe Ipp MD, Gordon J.G. Asmundson PhD, Michael J. Rieder MD PhD, \\ Kate Robson, Elizabeth Uleryk MLS, Martin M. Antony PhD, Vinita Dubey MD, Anita Hanrahan RN, \\ Donna Lockett PhD, Jeffrey Scott MD, Elizabeth Votta Bleeker PhD; HELPinKids\&Adults
}

CMAJ Podcasts: author interview at soundcloud.com/cmajpodcasts/150391-guide

$\mathrm{P}$ ain from vaccine injections is common, and concerns about pain contribute to vaccine hesitancy across the lifespan..$^{1,2}$ Noncompliance with vaccination compromises the individual and community benefits of immunization by contributing to outbreaks of vaccinepreventable diseases. Individuals may also engage in broader noncompliant behaviours if they acquire a fear of needles as a result of negative vaccination experiences. ${ }^{3}$ There are many evidence-based treatments to mitigate pain at the time of vaccination; however, most are not routinely used. ${ }^{4,5}$ An independent, cross-Canada multidisciplinary team, Help Eliminate Pain in Kids (HELPinKIDS), assembled in 2008 to tackle this gap in clinical care. In 2010, the HELPinKIDS team published the first clinical practice guideline on reducing pain during childhood vaccination. ${ }^{6}$ There are currently no guidelines on reducing pain during vaccination in adults.

\section{Scope}

The current guideline expands on and updates the 2010 guideline with recommendations across the lifespan. This enhanced scope led to a revised team name of HELPinKids\&Adults. The intended audience is all health care providers who administer vaccine injections. Recommendations for the management of fear in individuals with high levels of needle fear (i.e., individuals with persistent, intense apprehension of or fear in response to a needle procedure, who may endure needles with intense distress or avoidance) are reported separately, as they require knowledge and skills beyond those of practitioners who usually give vaccinations (C.M.M., unpublished data, 2015). Delayed pain (hours to days after injection) was not considered in this guideline.

\section{Methods}

\section{Team composition}

The HELPinKids\&Adults team included 25 individuals from across Canada with expertise in pain, fear, medicine, nursing, pharmacy, psychology, vaccinology, infectious diseases, epidemiology, guideline development, knowledge translation (KT), library sciences, public health, family advisory/advocacy and health policy. Eighteen members of the HELPinKids\&Adults team formed the guideline panel group.

The project was funded by the Canadian Institutes of Health Research, which had no input into the guideline. Financial and intellectual conflicts of interest were disclosed by all members. Individuals with self-identified conflicts were allowed to participate in all discussions, but were excluded from voting on guideline recommendations in areas of conflict. One government agency representative was an observer and did not participate in voting on recommendations. Individuals from industries manufacturing or distributing vaccines or pain treatments were excluded from participating.

\section{Guideline development}

We used the AGREE II (Appraisal of Guidelines for Research and Evaluation II) tool (www.agree trust.org) as the overarching methodology for guideline development. GRADE (Grading of Recom-
Competing interests: See end of article.

This article has been peer reviewed.

Correspondence to: Anna Taddio, anna.taddio@utoronto.ca CMAJ 2015. DOI:10.1503 /cmaj.150391 
mendations Assessment, Development and Evaluation) (www.gradeworkinggroup.org/publications/ jce_series.htm) and Cochrane (http://handbook. cochrane.org) methods provided the general framework for the development of recommendations and the synthesis of research evidence (Box 1).

All members of the HELPinKids\&Adults team participated in delineating the scope and clinical questions, and reviewed and approved the recommendations. The guideline panel group reviewed the evidence base and approved the first draft of the recommendations before consideration by the whole team. Two smaller working groups oversaw the development of the evidence base (Evidence Lead group) and knowledge translation (KT group) aspects. The chair (A.T.) oversaw all aspects of the project.

Practice recommendations were made for 49 clinical questions organized into five domains of pain management interventions (the " $5 \mathrm{P}$ " approach): procedural, physical, pharmacologic, psychological and process.

We identified relevant articles by searching MEDLINE, Embase, PsycINFO, CINAHL and ProQuest Dissertations \& Theses Global from their date of inception until Feb. 26, 2015. Systematic reviews were carried out for each domain; the complete methodology used and results are published separately. ${ }^{7-13}$ Self-reported pain was typically identified as the critically important outcome in studies; however, related outcomes, such as self-reported fear and, in the absence of selfreport (e.g., in infants and young children), observer-rated distress, were often included.

\section{Box 1: Summary of approach to guideline development} and recommendations

- The GRADE (Grading of Recommendations Assessment, Development and Evaluation) system provided the general framework for the formulation of recommendations and the synthesis of the research evidence.

- We rated candidate clinical questions; a two-thirds majority was set as the cut-off for inclusion in the guideline.

- We ranked the importance of each outcome on a scale of 1 to 9. Outcomes with scores from 7 to 9 were classified as critically important, those with scores from 4 to 6 were classified as important, and those with scores from 1 to 3 were disregarded. Critically important outcomes were prioritized for decision-making.

- We performed systematic reviews for all included questions.

- Quality of evidence across critical and important outcomes was assessed as very low, low, moderate or high on the basis of five factors: methodologic limitations, inconsistency, indirectness, imprecision and publication bias.

- The overall quality was assessed based on the lowest confidence for critical outcomes only.

- We categorized recommendations as strong or weak on the basis of four factors: balance between benefits and harms, strength of evidence for critical outcomes, variability in patient values and preferences, and resource implications.

- Interventions with a large benefit and higher strength of evidence were more likely to receive a strong recommendation.
The perspective of the individual undergoing vaccination was prioritized for decision-making. Because pain is an iatrogenic harm of vaccination, even small mitigation benefits were considered to be clinically significant. Recommendations were generally applied to broad developmental stages: infants and young children $(\leq 3 \mathrm{yr})$, children (3-12 $\mathrm{yr})$, adolescents (12-17 yr) and adults $(\geq 18 \mathrm{yr})$. Where deemed appropriate, further subdivisions were made or categories collapsed.

The guideline was reviewed using the AGREE II framework by individuals and organizations, including the World Health Organization. Changes were made to address concerns raised and then the guideline was finalized.

\section{Recommendations}

The recommendations are summarized in Table 1 and in age-based algorithms (Appendices 1-4, available at www.cmaj.ca/lookup/suppl/ doi:10.1503/cmaj.150391/-/DC1.) Strong recommendations are reviewed below.

\section{Procedural interventions (injection techniques)}

We recommend that no aspiration be used during intramuscular vaccine injections in individuals of all ages (strong recommendation; very low confidence in estimates of effect).

Aspiration, a long-standing practice with injection of medications, can increase pain because of the combined effects of a longer needle dwelling time in the tissues and sheering action (wiggling) of the needle. In two studies including 313 infants, there was a benefit to not aspirating on infant acute distress (standardized mean difference $[\mathrm{SMD}]-0.82,95 \%$ confidence interval $[\mathrm{CI}]$ -1.18 to -0.46$).{ }^{8}$ Aspiration is unnecessary for vaccine injections because of the lack of major blood vessels in the anatomic sites used for injection. ${ }^{14}$ In many countries, auto-disable syringes are already used, which preclude aspiration. Slight bleeding at the injection site is common with vaccine injections and does not signal incorrect injection technique. There are no documented harms of not aspirating before vaccination. It is a cost-neutral intervention for pain mitigation.

We recommend injecting the most painful vaccine last (rather than first) during vaccine injections in individuals of all ages (strong recommendation; moderate confidence in estimates of effect).

Many individuals receive more than one vaccine injection at a single visit. The order of vaccine injection matters to overall pain because some vaccines are inherently more painful than others, and pain can escalate with each subsequent injection 
(i.e., increased pain intensity following repeated painful stimuli, or hyperalgesia). ${ }^{15}$ In two studies including 196 infants, lower overall infant acute distress was observed when the most painful vaccine was given last (SMD $-0.69,95 \% \mathrm{CI}-0.98$ to $-0.40){ }^{8}$ There are no cost implications or identified harms from this intervention. Examples of painful vaccines that should be given last include M-M-R II and Prevnar. 6,8

\section{Physical interventions (body position and activity)}

We recommend breastfeeding be used during vaccine injections in children two years and younger (strong recommendation; very low confidence in estimates of effect).
Breastfeeding is one of the most important factors in promoting optimal health and is recommended for infants up to two years or beyond (www.who.int/nutrition/topics/infant feeding_recommendation/en). Breastfeeding is hypothesized to reduce distress via multiple mechanisms, including physical comfort, sucking, distraction and ingestion of sweet-tasting and other substances that may have, individually and together, distress-relieving effects. A meta-analysis including 792 infants showed a large benefit of breastfeeding during vaccination (SMD -1.78 , $95 \% \mathrm{CI}-2.35$ to -1.22$).{ }^{9}$ Breastfeeding is a costneutral intervention and does not require additional time beyond the need to latch the infant. Some privacy and a chair are suggested. Alternatives to

Table 1 (part 1 of 3): Recommendations for reducing pain during vaccine injections

\begin{tabular}{|c|c|c|c|c|c|c|}
\hline Treatment & Recommendation & Confidence & $\begin{array}{l}\text { Infants and } \\
\text { young children } \\
\text { ( } \leq 3 \mathrm{yr})\end{array}$ & $\begin{array}{l}\text { Children } \\
\text { (3-12 yr) }\end{array}$ & $\begin{array}{l}\text { Adolescents } \\
(12-17 \mathrm{yr})\end{array}$ & $\begin{array}{l}\text { Adults } \\
\text { ( } \geq 18 \mathrm{yr})\end{array}$ \\
\hline \multicolumn{7}{|c|}{ Strong recommendations } \\
\hline \multicolumn{7}{|l|}{ Procedural interventions } \\
\hline No aspiration & $\begin{array}{l}\text { We recommend no aspiration during } \\
\text { intramuscular vaccine injections }\end{array}$ & Very low & Yes & Yes & Yes & Yes \\
\hline Order of injection & $\begin{array}{l}\text { We recommend injecting the most painful } \\
\text { vaccine last during vaccine injections }\end{array}$ & Moderate & Yes & Yes & Yes & Yes \\
\hline \multicolumn{7}{|l|}{ Physical interventions } \\
\hline Breastfeeding* & $\begin{array}{l}\text { We recommend breastfeeding during } \\
\text { vaccine injections }\end{array}$ & Very low & $\begin{array}{l}\text { Yes } \\
(\leq 2 \mathrm{yr})\end{array}$ & - & - & - \\
\hline $\begin{array}{l}\text { Positioning: } \\
\text { skin-to-skin contact } †\end{array}$ & $\begin{array}{l}\text { We recommend skin-to-skin contact during } \\
\text { vaccine injections }\end{array}$ & Moderate & $\begin{array}{l}\text { Yes } \\
(\leq 1 \mathrm{mo})\end{array}$ & - & - & - \\
\hline \multirow[t]{2}{*}{ Positioning: holding† } & $\begin{array}{l}\text { We recommend holding during vaccine } \\
\text { injections }\end{array}$ & Very low & Yes & - & - & - \\
\hline & $\begin{array}{l}\text { If holding is not used during vaccine } \\
\text { injections, we recommend a combined } \\
\text { holding intervention (including patting and/ } \\
\text { or rocking) after vaccine injections }\end{array}$ & Low & Yes & - & - & - \\
\hline Positioning: sitting up & $\begin{array}{l}\text { We recommend sitting up during vaccine } \\
\text { injections }\end{array}$ & Low & - & Yes & Yes & Yes \\
\hline \multicolumn{7}{|c|}{ Pharmacologic interventions } \\
\hline Topical anesthetics & $\begin{array}{l}\text { We recommend topical anesthetics before } \\
\text { vaccine injections }\end{array}$ & Very low & Yes & Yes & $-\S$ & $-\S$ \\
\hline \multirow[t]{2}{*}{$\begin{array}{l}\text { Sweet-tasting } \\
\text { solutionst‡ }\end{array}$} & $\begin{array}{l}\text { We recommend sucrose solutions before } \\
\text { vaccine injections }\end{array}$ & Moderate & $\begin{array}{l}\text { Yes } \\
(\leq 2 \mathrm{yr})\end{array}$ & - & - & - \\
\hline & $\begin{array}{l}\text { We recommend glucose solutions before } \\
\text { vaccine injections }\end{array}$ & Moderate & $\begin{array}{l}\text { Yes } \\
(\leq 2 \mathrm{yr})\end{array}$ & - & - & - \\
\hline \multicolumn{7}{|l|}{ Process interventions } \\
\hline Education of clinicians & $\begin{array}{l}\text { We recommend education of clinicians } \\
\text { administering vaccine injections about } \\
\text { vaccine injection pain management }\end{array}$ & Low & Yes & Yes & Yes & Yes \\
\hline Parent presence & $\begin{array}{l}\text { We recommend presence of parents during } \\
\text { vaccine injections }\end{array}$ & Very low & Yes & $\begin{array}{l}\text { Yes } \\
(\leq 10 \mathrm{yr})\end{array}$ & - & - \\
\hline \multirow[t]{2}{*}{ Education of parents } & $\begin{array}{l}\text { We recommend education of parents about } \\
\text { pain management for vaccine injection } \\
\text { before the day of vaccination }\end{array}$ & Low & Yes & Yes & Yes & - \\
\hline & $\begin{array}{l}\text { We recommend education of parents about } \\
\text { pain management for vaccine injection on } \\
\text { the day of vaccination }\end{array}$ & Very low & Yes & Yes & Yes & - \\
\hline $\begin{array}{l}\text { Education of } \\
\text { individuals } \\
\text { undergoing } \\
\text { vaccination }\end{array}$ & $\begin{array}{l}\text { We recommend education of individuals } \\
\text { about pain management for vaccine } \\
\text { injection on the day of vaccination }\end{array}$ & Very low & - & Yes & Yes & Yes \\
\hline
\end{tabular}


breastfeeding include bottle-feeding with expressed breast milk or formula throughout the procedure, which simulates aspects of breastfeeding. Other alternatives are described below.

We recommend holding be used (rather than the child lying supine) during vaccine injections in children three years and younger (strong recommendation; very low confidence in estimates of effect).

Positioning that is comfortable and promotes proximity soothing from a caregiver should be used. ${ }^{16}$ Neonates that are not breastfed can be positioned skin-to-skin (also known as "kangaroo care"), which involves placing a diaper-clad baby prone on the mother's bare chest before commencing vaccine injection and continuing during and afterwards. In three studies including 736 neonates, skin-to-skin contact reduced acute distress during the procedure (SMD $-0.65,95 \% \mathrm{CI}$ -1.05 to -0.25$).{ }^{8}$ Holding infants during vaccination reduces acute distress (SMD $-1.25,95 \%$ CI -2.05 to $-0.46 ; n=107) .{ }^{8}$ Holding interventions

Table 1 (part 2 of 3): Recommendations for reducing pain during vaccine injections

\begin{tabular}{|c|c|c|c|c|c|c|}
\hline Treatment & Recommendation & Confidence & $\begin{array}{l}\text { Infants and } \\
\text { young children } \\
\text { ( } \leq 3 \mathrm{yr})\end{array}$ & $\begin{array}{l}\text { Children } \\
(3-12 \mathrm{yr})\end{array}$ & $\begin{array}{l}\text { Adolescents } \\
(12-17 \mathrm{yr})\end{array}$ & $\begin{array}{l}\text { Adults } \\
\text { ( } \geq 18 \mathrm{yr})\end{array}$ \\
\hline \multicolumn{7}{|c|}{ Weak recommendations } \\
\hline \multicolumn{7}{|l|}{ Procedural interventions } \\
\hline \multirow[t]{2}{*}{$\begin{array}{l}\text { Simultaneous } \\
\text { injection }\end{array}$} & $\begin{array}{l}\text { We suggest simultaneous injections (rather } \\
\text { than sequential injections) during vaccine } \\
\text { injections }\end{array}$ & Low & Yes ( $\leq 1$ yr)§ & $-\S$ & - & - \\
\hline & $\begin{array}{l}\text { We suggest against simultaneous injections } \\
\text { during vaccine injections }\end{array}$ & Very low & $\begin{array}{l}\text { Yes§ } \\
(1-3 \mathrm{yr})\end{array}$ & $\begin{array}{l}\text { Yes } \\
(\leq 10 \mathrm{yr})\end{array}$ & - & - \\
\hline Vastus lateralis & $\begin{array}{l}\text { We suggest the vastus lateralis (rather than } \\
\text { the deltoid) as the site of injection during } \\
\text { vaccine injections }\end{array}$ & Low & $\begin{array}{l}\text { Yes } \\
(\leq 11 \mathrm{mo})\end{array}$ & - & - & - \\
\hline \multicolumn{7}{|l|}{ Physical interventions } \\
\hline Breastfeeding* & $\begin{array}{l}\text { If breastfeeding is not used during vaccine } \\
\text { injections, we suggest breastfeeding before } \\
\text { vaccine injections }\end{array}$ & Low & $\begin{array}{l}\text { Yes } \\
(\leq 2 \mathrm{yr})\end{array}$ & - & - & - \\
\hline Nonnutritive sucking $†$ & $\begin{array}{l}\text { We suggest nonnutritive sucking (using a } \\
\text { thumb/finger, pacifier) during vaccine } \\
\text { injections }\end{array}$ & Low & $\begin{array}{l}\text { Yes } \\
(\leq 2 \mathrm{yr})\end{array}$ & - & - & - \\
\hline $\begin{array}{l}\text { Vibrating device } \\
\text { with cold }\end{array}$ & $\begin{array}{l}\text { We suggest an external vibrating device } \\
\text { with cold during vaccine injections }\end{array}$ & Low & - & Yes & Yes & - \\
\hline Muscle tension & $\begin{array}{l}\text { We suggest muscle tension for vaccine } \\
\text { injections in individuals with a history of } \\
\text { fainting }\end{array}$ & Very low & - & $\begin{array}{l}\text { Yes } \\
(\geq 7 \mathrm{yr})\end{array}$ & Yes & Yes \\
\hline $\begin{array}{l}\text { Manual tactile } \\
\text { stimulation }\end{array}$ & $\begin{array}{l}\text { We suggest against manual tactile } \\
\text { stimulation during vaccine injections }\end{array}$ & Very low & Yes & Yes & Yes & Yes \\
\hline Warming the vaccine & $\begin{array}{l}\text { We suggest against warming the vaccine } \\
\text { before vaccine injections }\end{array}$ & Low & Yes & Yes & Yes & Yes \\
\hline \multicolumn{7}{|c|}{ Pharmacologic interventions } \\
\hline Topical anesthetics & $\begin{array}{l}\text { We suggest topical anesthetics before } \\
\text { vaccine injections }\end{array}$ & Moderate & $-\S$ & $-\S$ & Yes & Yes \\
\hline $\begin{array}{l}\text { Topical anesthetics } \\
\text { and breastfeeding* }\end{array}$ & $\begin{array}{l}\text { We suggest combining topical anesthetics } \\
\text { before vaccine injections and breastfeeding } \\
\text { during vaccine injections }\end{array}$ & Low & $\begin{array}{l}\text { Yes } \\
(\leq 2 \mathrm{yr})\end{array}$ & - & - & - \\
\hline $\begin{array}{l}\text { Sweet-tasting } \\
\text { solutions and } \\
\text { nonnutritive } \\
\text { sucking†‡ }\end{array}$ & $\begin{array}{l}\text { We suggest sweet-tasting solutions (sucrose, } \\
\text { glucose) before vaccine injections and } \\
\text { nonnutritive sucking (thumb/finger, } \\
\text { pacifier) during vaccine injections }\end{array}$ & Very low & $\begin{array}{l}\text { Yes } \\
(\leq 2 \mathrm{yr})\end{array}$ & - & - & - \\
\hline \multirow[t]{2}{*}{ Vapocoolants } & $\begin{array}{l}\text { We suggest against applying vapocoolants } \\
\text { before vaccine injections }\end{array}$ & Low & Yes & Yes & Yes & $-\S$ \\
\hline & $\begin{array}{l}\text { We suggest that vapocoolant spray be used } \\
\text { before vaccine injections }\end{array}$ & Low & $-\S$ & $-\S$ & $-\S$ & Yes \\
\hline Acetaminophen & $\begin{array}{l}\text { We suggest against giving acetaminophen } \\
\text { before vaccine injections }\end{array}$ & Low & Yes & Yes & Yes & Yes \\
\hline Ibuprofen & $\begin{array}{l}\text { We suggest against giving ibuprofen before } \\
\text { vaccine injections }\end{array}$ & Very low & Yes & Yes & Yes & Yes \\
\hline $\begin{array}{l}\text { Sweet-tasting } \\
\text { solutions and } \\
\text { breastfeeding }\end{array}$ & $\begin{array}{l}\text { We suggest against using sweet-tasting } \\
\text { solutions (sucrose, glucose) and } \\
\text { breastfeeding in combination before } \\
\text { vaccine injections }\end{array}$ & Low & $\begin{array}{l}\text { Yes } \\
(\leq 2 \mathrm{yr})\end{array}$ & - & - & - \\
\hline
\end{tabular}


applied after vaccine injections should combine patting and/or rocking. ${ }^{8}$

We recommend sitting upright be used (rather than the individual lying supine) during vaccine injections in children three years and older and adults (strong recommendation; low confidence in estimates of effect).

Sitting upright promotes a sense of control in individuals undergoing vaccination, which can have a positive impact on their experience of pain. Sitting upright has been shown to decrease fear (SMD $-0.39,95 \% \mathrm{CI}-0.77$ to $-0.01 ; n=107$ ) and observed distress (SMD -10.3, 95\% CI -20.18 to $-0.42 ; n=107)$ in children. ${ }^{8}$ Children can sit on a parent's lap; this can also assist with keeping still the limbs to be vaccinated. Forcibly restraining children should be avoided because this can increase fear. Children, adolescents and adults can sit upright on their own.

\section{Pharmacologic interventions (pain medicine)}

We recommend topical anesthetics be applied before vaccine injections in children 12 years and younger (strong recommendation; very low confidence in estimates of effect).

Topical anesthetics are local anestheticcontaining creams, gels and patches that block transmission of pain signals from the skin. ${ }^{17}$ Topical anesthetics are a well-established therapy for the mitigation of needle-related pain in individuals of all ages. In a meta-analysis including 1424 children undergoing vaccination, there was a sub-

Table 1 (part 3 of 3): Recommendations for reducing pain during vaccine injections

\begin{tabular}{|c|c|c|c|c|c|c|}
\hline Treatment & Recommendation & Confidence & $\begin{array}{l}\text { Infants and } \\
\text { young children } \\
\qquad(\leq 3 \mathrm{yr})\end{array}$ & $\begin{array}{l}\text { Children } \\
\text { (3-12 yr) }\end{array}$ & $\begin{array}{l}\text { Adolescents } \\
(12-17 \mathrm{yr})\end{array}$ & $\begin{array}{l}\text { Adults } \\
(\geq 18 \mathrm{yr})\end{array}$ \\
\hline \multicolumn{7}{|c|}{ Weak recommendations cont'd } \\
\hline \multicolumn{7}{|c|}{ Psychological interventions } \\
\hline $\begin{array}{l}\text { Verbal signal of } \\
\text { impending procedure }\end{array}$ & $\begin{array}{l}\text { We suggest a verbal signal of the } \\
\text { impending procedure ( } \mathrm{v} \text {. a signal of } \\
\text { impending pain) before vaccine injections }\end{array}$ & Very low & Yes & Yes & Yes & Yes \\
\hline \multirow[t]{8}{*}{ Distraction } & $\begin{array}{l}\text { We suggest directed video distraction } \\
\text { during vaccine injections }\end{array}$ & Very low & Yes & $-\S$ & - & - \\
\hline & $\begin{array}{l}\text { We suggest directed toy distraction during } \\
\text { vaccine injections }\end{array}$ & Very low & Yes & - & - & - \\
\hline & $\begin{array}{l}\text { We suggest nondirected toy distraction } \\
\text { during vaccine injections }\end{array}$ & Very low & Yes & - & - & - \\
\hline & $\begin{array}{l}\text { We suggest verbal distraction during } \\
\text { vaccine injections }\end{array}$ & Low & - & Yes & - & - \\
\hline & $\begin{array}{l}\text { We suggest video distraction during vaccine } \\
\text { injections }\end{array}$ & Very low & $-\S$ & Yes & - & - \\
\hline & $\begin{array}{l}\text { We suggest music distraction during vaccine } \\
\text { injections }\end{array}$ & Low & - & Yes & $-\S$ & $-\S$ \\
\hline & $\begin{array}{l}\text { We suggest against music distraction during } \\
\text { vaccine injections }\end{array}$ & Very low & - & $-\S$ & Yes & Yes \\
\hline & $\begin{array}{l}\text { We suggest against visual distraction during } \\
\text { vaccine injections }\end{array}$ & Very low & - & - & - & Yes \\
\hline \multirow[t]{4}{*}{ Breathing distraction } & $\begin{array}{l}\text { We suggest breathing with a toy distraction } \\
\text { (e.g., blowing bubbles, pinwheel) during } \\
\text { vaccine injections }\end{array}$ & Very low & - & Yes & - & - \\
\hline & $\begin{array}{l}\text { We suggest against breathing without a toy } \\
\text { distraction (blowing, deep breathing) } \\
\text { during vaccine injections }\end{array}$ & Very low & - & Yes & - & - \\
\hline & $\begin{array}{l}\text { We suggest against breathing interventions } \\
\text { (cough) during vaccine injections }\end{array}$ & Low & - & Yes & Yes & $-\S$ \\
\hline & $\begin{array}{l}\text { We suggest breathing interventions (cough, } \\
\text { breath-hold) during vaccine injections }\end{array}$ & Very low & - & $-\S$ & $-\S$ & Yes \\
\hline Using suggestion & $\begin{array}{l}\text { We suggest against using false suggestion } \\
\text { during vaccine injections }\end{array}$ & Low & Yes & Yes & Yes & Yes \\
\hline Using reassurance & $\begin{array}{l}\text { We suggest against using repeated } \\
\text { reassurance during vaccine injections }\end{array}$ & Very low & Yes & Yes & Yes & Yes \\
\hline \multicolumn{7}{|c|}{$\begin{array}{l}\text { *Alternatively, bottle feeding with expressed breast milk or formula can be used, or combined interventions that simulate breastfeeding (e.g., holding, sweet-tasting solution, } \\
\text { sucking), as appropriate. } \\
\text { †If not breastfeeding. } \\
\text { †Alternatively, if oral rotavirus vaccine is being administered at the same time as injectable vaccines, rotavirus vaccine can be given first as it contains sucrose. } \\
\text { \$See elsewhere in the table for a recommendation in this age group. }\end{array}$} \\
\hline
\end{tabular}


stantial benefit of topical anesthetics on acute distress (SMD $-0.91,95 \% \mathrm{CI}-1.36$ to -0.47 ). ${ }^{9}$ There is no evidence of an adverse effect of topical anesthetics on the vaccine immune response. ${ }^{9}$ The provision of topical anesthetics should be a standard preventive measure for children, who cannot advocate for themselves and are at risk of long-term harm from unmitigated pain due to the development of needle fears. The majority of children are afraid of needles and report a preference for analgesics to be used. ${ }^{2,18}$ Because topical anesthetics incur additional time and costs, their use requires some planning. In many cases, they can be accommodated in usual clinic waiting times. ${ }^{19}$ Otherwise, they can be applied before clinic arrival.

We recommend giving sucrose solution before vaccine injections in children two years and younger (strong recommendation; moderate confidence in estimates of effect).

Children who are not breastfed during vaccine injections can be given sweet-tasting solutions. In the hospital setting, sweet-tasting solutions are an established treatment for pain. Their mechanism of action is not known, but may involve release of endogenous opioids and distraction. In a meta-analysis including 2071 infants undergoing vaccination, the benefit of sucrose solution on infant distress was significant (SMD $-0.76,95 \% \mathrm{CI}-1.19$ to -0.34 ). The typical dose is $2 \mathrm{~mL}$ of a $24 \%$ to $50 \%$ strength solution administered about one to two minutes before injection; glucose can be used if sucrose is not available. This intervention requires additional resources for acquisition of commercially available preparations or manufacturing by clinicians or parents. Alternatively, for infants scheduled to receive oral rotavirus vaccine at the same time as injectable vaccines, rotavirus can be given first because it contains sucrose (as a flavouring agent), which obviates the need for sweet-tasting solutions. ${ }^{20}$

\section{Process interventions (education and implementation)}

We recommend education of clinicians administering vaccine injections about pain management (strong recommendation; low confidence in estimates of effect).

Clinicians administering vaccinations are required to be competent in vaccine administration techniques, and this includes pain mitigation. Clinician education increases the use of pain interventions during vaccination (SMD $0.66,95 \%$ CI 0.47 to $0.85 ; n=459) .{ }^{13}$

We recommend that parents be present during vaccine injections in children 10 years and younger (strong recommendation; very low confidence in estimates of effect).
Children show lower levels of distress when parents stay before vaccine injections than when parents leave (SMD $-0.85,95 \%$ CI 1.35 to $-0.35 ; n=67$ ) and prefer to have their parents present. ${ }^{13}$ Family-centred health care promotes caregiver presence whenever possible. ${ }^{21}$ Because parents' behaviour can influence a child's level of distress, education of parents is recommended to facilitate child coping and to alleviate pain, fear and distress (see below).

We recommend education of parents about pain management before the day of vaccination (strong recommendation; low confidence in estimates of effect).

Parents want to learn about strategies for pain mitigation. ${ }^{2}$ Education of parents ahead of time increases use of pain interventions during vaccination (relative risk [RR] 2.08, 95\% CI 1.51 to $2.86 ; n=300) .{ }^{13}$

We recommend education of parents about pain management on the day of vaccination (strong recommendation; very low confidence in estimates of effect).

Educating parents on the day of vaccination increases use of pain interventions during vaccination (RR 2.42, 95\% CI 1.47 to $3.99 ; n=239$ ). ${ }^{13}$ Opportunities to learn ahead of time support planning and practice.

We recommend education of children three years and older and adults about pain management on the day of vaccination (strong recommendation; very low confidence in estimates of effect).

Individuals undergoing vaccination should be given information about what will happen (procedural information), how it will feel (sensory information) and how to cope (training in strategies to mitigate pain and fear). ${ }^{22-24}$ Information should mostly be given in advance. At the time of the procedure, the focus should be on neutral information about the procedure and coping strategies rather than threatening sensory information that can increase fear. There is evidence that education reduces preprocedural fear in children undergoing vaccination (SMD $-0.67,95 \%$ CI -1.28 to $-0.07 ; n=51) .{ }^{13}$

\section{Implementation}

No single intervention included in this guideline is expected to prevent all pain (i.e., achieve a level of pain of " 0 "). Individual interventions can be combined, as appropriate, to improve pain relief. For young and school-aged children, because of the high levels of distress with vaccine injections and higher potential for long-term 
harm (i.e., development of needle fear and health care avoidance), a more comprehensive and consistent approach is recommended. With maturity, a more self-directed and individualized approach can be used.

Pain mitigation is considered part of good vaccination clinical practice by the World Health Organization, which has accepted the most practical interventions from this guideline for global implementation. ${ }^{25}$ All involved in vaccination programs need to identify and support clinician interest, willingness and ability to adopt these guideline recommendations to achieve best practices. Additional resources (e.g., supplies, personnel) may be required to educate and support clinicians, parents and individuals to implement these recommendations.

Methods already used for education about vaccination (e.g., verbal instruction, pamphlets, videos) are effective for education about pain mitigation. Sample resources are currently available from Immunize Canada (www.immunize. ca) and HELPinKids\&Adults (http://phm. utoronto.ca/helpinkids). Training can occur across various different clinical (e.g., hospital, outpatient clinic) and educational (e.g., prenatal class, school) settings.

Importantly, many pain mitigation interventions can be offered for little or no cost. Even for those with costs, the costs may be offset by avoiding the costs of subsequent harm from unmitigated pain and fear, including the negative impact on health outcomes due to vaccine hesitancy and noncompliance with other health care interventions, and the costs for treatment of needle fears that have developed due to poorly managed pain. Performance metrics can include clinical indicators (e.g., pain intensity, fear intensity), process indicators (e.g., use of pain interventions, compliance with vaccination) and conceptual indicators (e.g., knowledge, satisfaction). Appendix 5 (available at www.cmaj.ca/lookup/suppl/ doi:10.1503/cmaj.150391/-/DC1) and a global vaccine safety research network (https://brighton collaboration.org ${ }^{26}$ offer some sample tools for assessing pain and related outcomes, and documenting pain interventions used.

We plan to update the guideline in the next 5-10 years (2019-2024), depending on the availability of new research evidence and project funding.

\section{Other guidelines}

The differences between the original 2010 guideline ${ }^{6}$ and the current guideline are summarized in Appendix 6, available at www.cmaj.ca/lookup/ suppl/doi:10.1503/cmaj.150391/-/DC1.

\section{Gaps in knowledge}

The guideline recommendations are limited to the available evidence, and certain recommendations have more research support than others. There was a noticeable gap in research evidence for adolescent and adult populations, and mass vaccination settings, even though concerns about pain and fear are well documented and contribute to vaccine hesitancy. School-based vaccinations should be specifically targeted to facilitate more positive experiences with health care for children.

Data are needed on the painfulness of different vaccines (including their route of administration), aspects of vaccine injection technique (e.g., speed of injection and injection in a single limb for multiple vaccine injections), and vaccine formulations and delivery systems that minimize pain. Given the potential role of memory for pain and fear in subsequent experiences of pain, ${ }^{27}$ research is needed to examine the efficacy of interventions for memory reframing. Studies on the impact of pain interventions on future pain and vaccine compliance are also warranted to show the long-term impact of pain interventions.

\section{Conclusion}

Pain during vaccination is an important concern across the lifespan. This guideline provides recommendations for interventions that can mitigate vaccination pain. Many interventions are feasible across vaccination settings. The fulllength guideline is available in Appendix 7, available at www.cmaj.ca/lookup/suppl/doi: 10.1503/cmaj.150391/-/DC1.

\section{References}

1. Taddio A, Chambers $\mathrm{C}$, Halperin $\mathrm{S}$, et al. Inadequate pain management during childhood immunization: the nerve of it. Clin Ther 2009;31(Suppl 2):S152-67.

2. Taddio A, Ipp M, Thivakaran S, et al. Survey of the prevalence of immunization non-compliance due to needle fears in children and adults. Vaccine 2012;30:4807-12.

3. McMurtry CM, Pillai Riddell R, Taddio A, et al. Far from "just a poke": common painful needle procedures and the development of needle fear. Clin J Pain. In press.

4. Harrison D, Elia S, Royle J, et al. Pain management strategies used during early childhood immunisation in Victoria. J Paediatr Child Health 2013;49:313-8.

5. Taddio A, Manley J, Potash L, et al. Routine immunization practices: use of topical anesthetics and oral analgesics. Pediatrics 2007;120:e637-43.

6. Taddio A, Appleton M, Bortolussi R, et al. Reducing the pain of childhood vaccination: an evidence-based clinical practice guideline. CMAJ 2010;182:E843-55.

7. Taddio A, McMurtry CM, Shah V, et al. HELPinKids\&Adults Team. Methodology for knowledge synthesis of the management of vaccination pain and needle fear. Clin J Pain. In press.

8. Taddio A, Shah V, McMurtry CM, et al. HELPinKids\&Adults Team. Procedural and physical interventions for vaccine injections: systematic review of randomized controlled trials and quasi-randomized controlled trials. Clin J Pain. In press.

9. Shah V, Taddio A, McMurtry M, et al. HELPinKids\&Adults Team. Pharmacological and combined interventions to reduce vaccine injection pain in children and adults: systematic review and meta-analysis. Clin J Pain. In press. 
10. Pillai Riddell R, Taddio A, McMurtry CM, et al.; HELPinKIDS\&Adults Team. Psychological interventions for vaccine injections in young children 0 to 3 years: systematic review of randomized controlled trials and quasi-randomized controlled trials. Clin J Pain. In press.

11. Birnie KA, Chambers CT, Taddio A, et al. HELPinKids\&Adults Team. Psychological interventions for vaccine injections in children and adolescents: systematic review of randomized and quasi-randomized controlled trials. Clin J Pain. In press.

12. Boerner KE, Birnie KA, Chambers CT, et al HELPinKIDS\&Adults Team. Simple psychological interventions for reducing pain from common needle procedures in adults: systematic review of randomized and quasi-randomized controlled trials. Clin J Pain. In press.

13. Pillai Riddell R, Taddio A, McMurtry CM, et al HELPinKids\&Adults Team. Process interventions for vaccine injections: systematic review of randomized controlled trials and quasi-randomized controlled trials. Clin J Pain. In press.

14. General recommendations on immunization: recommendation of the Advisory Committee on Immunization Practice (ACIP). MMWR Recomm Rep 2011;60:1-64.

15. Ji RR, Kohno T, Moore KA, et al. Central sensitization and LTP: Do pain and memory share similar mechanisms? Trends Neurosci 2003;26:696-705.

16. Bowlby J. Attachment. 2nd ed. New York: Tavistock Institute of Human Relations; 1969 and 1982

17. McLure HA, Rubin AP. Review of local anaesthetic agents Minerva Anestesiol 2005;71:59-74.

18. Taddio A, Ilersich AF, Ilersich AN, et al. From the mouth of babes: Getting vaccinated doesn't have to hurt. Can J Infect Dis Med Microbiol 2014;25:196-200.

19. Taddio A, Hogan M-E, Gerges S, et al. Addressing parental concerns about pain during childhood vaccination: Is there enough time to include pain management in the ambulatory setting? Clin $J$ Pain 2012;28:238-42.

20. Taddio A, Flanders D, Weinberg E, et al. A randomized trial of rotavirus vaccine versus sucrose solution for vaccine injection pain. Vaccine 2015;33:2939-43.

21. Hutchfield K. Family-centred care: a concept analysis. $J A d v$ Nurs 1999;29:1178-87.

22. Jaaniste T, Hayes B, von Baeyer CL. Providing children with information about forthcoming medical procedures: a review and synthesis. Clin Psychol Sci Pract 2007;14:124-43.

23. Suls J, Wan CK. Effects of sensory and procedural information on coping with stressful medical procedures and pain: a metaanalysis. J Consult Clin Psychol 1989;57:372-9.

24. Blount RL, McCormick ML, MacLaren JE, et al. Preparing children for invasive procedures and surgery. In: Walco GA, Goldschneider KR, editors. Pain in children: a practical guide for primary care. Totowa (NJ): Humana Press; 2008: 93-9.

25. Meeting of the Strategic Advisory Group of Experts on immunization, April 2015: conclusions and recommendations. WHO Weekly Epidemiol Record 2015;90:261-80. Available: www. who.int/wer/2015/wer9022.pdf?ua=1 (accessed 2015 July 2).

26. Gidudu JF, Walco GA, Taddio A, et al. Immunization site pain: case definition and guidelines for collection, analysis, and presentation of immunization safety data. Vaccine 2012;30:4558 77.

27. Noel M, Chambers CT, McGrath PJ, et al. The influence of children's pain memories on subsequent pain experience. Pain 2012;153:1563-72.

Competing interests: Anna Taddio declares a grant from Pfizer, and study supplies from Natus and Ferndale. Christine Chambers declares consultation fees from AbbVie. Lucie Bucci declares a relationship with government agencies and grants from Merck, GlaxoSmithKline, Novartis, Sanofi and Pfizer. Eddy Lang is a member of the GRADE working group and declares consultation fees from the International Liaison Committee on Resuscitation. Scott Halperin declares grants from GlaxoSmithKline, Sanofi, Novartis, Pfizer, Merck, PREVENT (Pan-Provincial Vaccine Enterprise Inc.), Immunovaccine, Novavax, Janssen and Folia Biotech. No other competing interests were declared.

Affiliations: Leslie Dan Faculty of Pharmacy (Taddio), University of Toronto, and The Hospital for Sick Children, Toronto, Ont.; Department of Psychology (McMurtry), University of Guelph, Children's Health Research Institute, and Department of Paediatrics, Western University, London,
Ont.; Mount Sinai Hospital (Shah), and Institute of Health Policy, Management and Evaluation, Faculty of Medicine, University of Toronto, Toronto, Ont.; Department of Psychology (Pillai Riddell), York University, Toronto, Ont.; Departments of Pediatrics (Chambers), and Psychology and Neuroscience, Dalhousie University, and Centre for Pediatric Pain Research, IWK Health Centre, Halifax, NS; Center for Child Health, Behavior and Development (Noel), Seattle Children's Research Institute, Seattle, Wash.; Department of Pediatrics (MacDonald), Dalhousie University, IWK Health Centre and Canadian Center for Vaccinology, Halifax, NS; Centre for Effective Practice (Rogers), and Institute of Health Policy, Management and Evaluation, University of Toronto, Toronto, Ont.; Immunize Canada (Bucci), Canadian Public Health Association, Ottawa, Ont.; Child and Adolescent Health Program Committee (Mousmanis), The College of Family Physicians of Canada, Mississauga, Ont.; Alberta Health Services (Lang), and Cumming School of Medicine, University of Calgary, Calgary, Alta.; Departments of Pediatrics (Halperin), and Microbiology and Immunology, and Canadian Center for Vaccinology, Dalhousie University, IWK Health Centre, Halifax, NS; College of Pharmacy (Bowles), Dalhousie University, Halifax, NS; Immunization Programs and Vaccine Preventable Diseases Service (Halpert), BC Centre for Disease Control, Vancouver, BC; Department of Paediatrics (Ipp), The Hospital for Sick Children, and Faculty of Medicine, University of Toronto, Toronto, Ont.; Department of Psychology (Asmundson), Faculty of Arts, University of Regina, Regina, Sask.; Departments of Paediatrics (Rieder), Physiology and Pharmacology, and Medicine, Schulich School of Medicine \& Dentistry, Western University, London, Ont.; Canadian Family Advisory Network (Robson), Toronto, Ont.; E.M. Uleryk Consulting (Uleryk), Mississauga, Ont.; Department of Psychology (Antony), Ryerson University, Toronto, Ont.; Toronto Public Health (Dubey), Toronto, Ont.; Communicable Disease Control (Hanrahan), Alberta Health Services, Edmonton, Alta.; Bodhi Seed Center for Healing and Conscious Living (Lockett), Milton, Ont.; Department of Emergency Medicine (Scott), IWK Health Centre, Halifax, NS; Science Directorate (Votta Bleeker), Canadian Psychological Association, Ottawa, Ont.

Contributors: All of the authors contributed substantially to conception and design. Anna Taddio, C. Meghan McMurtry, Vibhuti Shah, Rebecca Pillai Riddell, Christine Chambers and Melanie Noel contributed to acquisition, analysis and interpretation of data. Anna Taddio and C. Meghan McMurtry drafted the article, which all of the authors revised. All of the authors gave final approval of the version to be published and agreed to act as guarantors of the work.

Funding: The Canadian Institutes of Health Research provided funding for HELPinKIDS\&Adults activities (KRS 132031). The Mayday Fund supported publication. The funding agencies did not have any input into the guideline.

Acknowledgement: Dianne Alexander, Manager, Immunization Policy and Programs, Public Health Division, Ontario Ministry of Health and Long-Term Care, participated as an observer.

Endorsing and supporting organizations: This guideline is endorsed by the following organizations: Canadian Association of Paediatric Health Centres, Canadian Child \& Youth Health Coalition, Canadian Family Advisory Network, Canadian Nursing Coalition for Immunization, Canadian Paediatric Society, Canadian Pharmacists Association, Canadian Psychological Association, Canadian Public Health Association, The College of Family Physicians of Canada, Immunize Canada, AnxietyBC, Nurse Practitioners' Association of Ontario. This guideline is supported by the following organizations: Canadian Center for Vaccinology, BC Centre for Disease Control. 